\title{
(C) 2014

\section{Kajian Kinerja Pemerintah Kelurahan dalam Mewujudkan Program Permukiman Green-Village di Kelurahan Gayamsari, Kota Semarang}

\author{
Astrini Ayu Puspita ${ }^{1}$ \\ Diterima : 30 Juni 2014 \\ Disetujui : 15 Juli 2014
}

\begin{abstract}
A settlement which is trying to promote ecological aspects are Gayamsari village, Semarang. The local government initiated a Gayamsari Green-village program, to prioritizing environmental friendly development. However, there are many problems that hamper the realization of green-village, there are lack of green space, flooding caused by inadequate drainage, and Gayamsari community's effort in realizing green-village is low. It shows that the performance of the village's government in greenvillage has not been optimally realized, because of many environment problems and the village's government has not been good enough to motivate Gayamsari's community in realizing green-village. The aim of this study is to assess the performance made by village's government of Gayamsari village in realizing green-village program. The results of this study shows that the performance of village's government in realizing green-village is good enoughthe positive factors of performance are good governance from village's government and good cooperation with community. Factors that cause the bad performance are, lack of implementation of green-village indicator and lack of monitoring activity from the village's government, so that the existing environmental activities are not sustainable.
\end{abstract}

Keywords: performance, village's government, gayamsari green-village program

\begin{abstract}
ABSTRAK
Permukiman yang mulai mencoba mengedepankan aspek ekologi adalah Kelurahan Gayamsari, Semarang. Pemerintah kelurahan menginisiasi program green-village dengan memprioritaskan pembangunan yang ramah lingkungan. Namun, masih terdapat permasalahan yang menghambat perwujudan green-village yaitu kurangnya ruang terbuka hijau, banjir yang disebabkan oleh drainase yang tidak memadai, dan upaya masyarakat yang rendah dalam mewujudkannya. Hal ini menunjukkan kinerja Kelurahan dalam mewujudkan green-village belum optimal, karena masih adanya permasalahan lingkungan dan kelurahan belum cukup baik memotivasi masyarakat dalam mewujudkannya. Tujuan penelitian ini untuk mengkaji kinerja pemerintah Kelurahan Gayamsari dalam mewujudkan program permukiman green-village. Metode yang digunakan adalah analisis deskriptif kuantitatif berupa analisis skoring. Hasil dari penelitian ini menunjukkan bahwa kinerja kelurahan dalam mewujudkan green-village cukup baik. Faktor kelebihan kinerja adalah sisi tata kelola kelurahan dan kerjasama dengan masyarakat. Faktor yang menyebabkan kekurangan yaitu kurangnya implementasi indikator green-village di lapangan, serta pemantauan kegiatan buruk, sehingga kegiatan lingkungan yang sudah berjalan tidak berkelanjutan.
\end{abstract}

Kata kunci: kinerja, pemerintah kelurahan, program gayamsari green-village

\footnotetext{
${ }^{1}$ Mahasiswa Magister Pembangunan Wilayah dan Kota, Undip, Semarang, Jawa Tengah Kontak Penulis: astriniayupuspita@gmail.com
} 


\section{PENDAHULUAN}

Pertumbuhan jumlah penduduk, khususnya di perkotaan semakin meningkat setiap tahunnya. Bahkan United Nation Department of Economic and Social Affairs (2009) memperkirakan bahwa pada tahun 2050, populasi dunia akan mencapai jumlah $84 \%$ dengan terkonsentrasi di daerah perkotaan. Hal tersebut menunjukkan bahwa kota semakin dihadapkan oleh permasalahan serius untuk memenuhi seluruh kebutuhan dan kepentingan masyarakatnya. Fenomena tersebut secara tidak langsung juga menyebabkan kebutuhan akan hunian dan lahan yang semakin meningkat, sehingga bentuk pembangunan lebih kearah kurang terkendali dan cenderung merusak sumberdaya alam serta mengurangi kawasan resapan air. Dampak lain, pertumbuhan jumlah penduduk diperkirakan akan terus menguras pemakaian energi dan air, peningkatan produksi sampah dan limbah, serta membebani pelayanan transportasi kota (Joga, 2013). Oleh karena itu pembangunan pada saat ini cenderung mengabaikan aspek lingkungan.

Adanya permasalahan lingkungan menuntut adanya sebuah konsep yang perlu diterapkan dan diutamakan dalam pembangunan saat ini, yaitu pembangunan berkelanjutan. Permasalahan lingkungan seperti perubahan iklim, pencemaran lingkungan, dan bencana alam saat ini menjadi permasalahan serius yang harus diatasi melalui konsep pembangunan berkelanjutan. Pentingnya konsep keberlanjutan ini perlu diterapkan pada skala lingkungan dari yang kecil hingga skala nasional atau negara, khususnya dari skala yang paling kecil yaitu lingkungan permukiman, mengingat prosentase terbesar penggunaan lahan perkotaan adalah untuk permukiman. Prioritas keberlanjutan dalam permukiman perkotaan terutama yaitu tidak merusak ekosistem lingkungan dan kelestarian sumberdaya alam. Perencanaan permukiman yang mengedepankan aspek lingkungan ini disebut sebagai permukiman berwawasan lingkungan atau sering disebut green-village.

Menurut Kadave et al (2012), Green-village adalah merupakan sebuah konsep yang menjaga sebuah kampung atau permukiman untuk mencapai pembangunan berkelanjutan, dengan tujuan perencanaan yang didasarkan pada konservasi lingkungan, energi, pengelolaan sampah, konservasi sumber air, dan sebagainya. Adanya konsep green-village ditujukan untuk mengatasi permasalahan lingkungan dengan prinsip hijau disetiap pembangunannya. Intinya adalah tetap melakukan konservasi hijau atau mempertahankan ruang terbuka hijau, memiliki perilaku ramah lingkungan, pengolahan sampah dan limbah, dan sebagainya. Konsep ecovillage/green-village juga tidak akan berhasil jika tidak didukung oleh pencapaian yang baik dari keempat aspek yaitu ekologi, ekonomi, sosial, dan kelembagaan yang baik (Suryani, 2011). Konsep green-village ini sangat tergantung pada aktor yang melaksanakannya. Aktor disini yaitu pemerintah sebagai institusi formal yang berwenang, dan masyarakat sebagai objek utama dalam pembangunan. Pemerintah sebagai institusi formal sudah seharusnya memainkan peran yang efektif dalam implementasi pembangunan berkelanjutan melalui perencanaan, kontrol pembangunan, dan manajemen permukiman sehingga dapat menjaga fungsi lingkungan. Oleh karena peranan dari institusi di tingkat lokal sangat penting di dalam mewujudkan green-village.

Permukiman yang mulai mencoba mengedepankan aspek ekologi adalah Kelurahan Gayamsari, Semarang. Pemerintah kelurahan menginisiasi program green-village dengan memprioritaskan pembangunan yang ramah lingkungan. Beberapa upaya yang dilakukan adalah peningkatan ruang terbuka hijau seperti pembuatan openspace, pengolahan sampah mandiri dan penggunaan teknologi ramah lingkungan seperti rain harvesting \& sumur resapan. Dari sisi kelembagaan, terdapat kelompok masyarakat peduli lingkungan, kelompok rumah sehat, yang 
mengkoordinir masyarakat dalam memaksimalkan upaya pengelolaan lingkungan. Namun, masih terdapat permasalahan yang menghambat perwujudan green-village yaitu kurangnya ruang terbuka hijau, banjir yang disebabkan oleh drainase yang tidak memadai, dan upaya masyarakat yang rendah dalam mewujudkannya. Hal ini menunjukkan kinerja Kelurahan dalam mewujudkan green-village belum optimal, karena masih adanya permasalahan lingkungan dan kelurahan belum cukup baik memotivasi masyarakat dalam mewujudkannya.

Kelurahan Gayamsari merupakan kawasan permukiman padat di pusat Kota Semarang, dengan pengembangan permukiman yang semakin pesat. Kelurahan Gayamsari memiliki kepadatan bangunan dalam kategori tinggi yaitu 97,2\%. Hal ini berpengaruh pada kurangnya ruang terbuka hijau sebagai area resapan air. Selain itu kondisi drainase yang kurang baik dan tersumbat sampah menyebabkan terjadinya banjir yang merugikan kawasan permukiman. Selain itu terdapat masalah kelembagaan seperti lemahnya kapasitas pemerintah kelurahan sendiri maupun lembaga masyarakat yang fokus pada kegiatan lingkungan, yang belum sepenuhnya melakukan perwujudan Kelurahan Gayamsari sebagai green-village. Dari sisi masyarakat, upaya masyarakat dalam pengelolaan lingkungan rendah karena belum sepenuhnya masyarakat sadar untuk melakukan upaya pengelolaan lingkungan permukiman. Sosialisasi dari kelurahan juga kurang sehingga masyarakat belum sepenuhnya sadar akan berperilaku ramah lingkungan. Oleh karena itu dapat dikatakan bahwa pada satu sisi pemerintah Kelurahan Gayamsari memiliki kinerja yang baik untuk meningkatkan kualitas ekologi melalui program green-village, namun masih belum optimal karena masih banyak terjadi permasalahan lingkungan yang belum dapat diatasi. Oleh karena itu menjadi penting dilakukan penelitian mengenai seberapa besar kinerja pemerintah kelurahan dalam mewujudkan permukiman green-village. Tujuan penelitian ini untuk mengkaji kinerja pemerintah Kelurahan Gayamsari dalam mewujudkan program permukiman green-village. Kawasan yang dijadikan objek penelitian adalah lingkungan permukiman Kelurahan Gayamsari, Kota Semarang yang berada di pusat Kecamatan Gayamsari Kota Semarang. Jarak Kelurahan Gayamsari dari pusat Kota Semarang kurang lebih $3 \mathrm{~km}$.

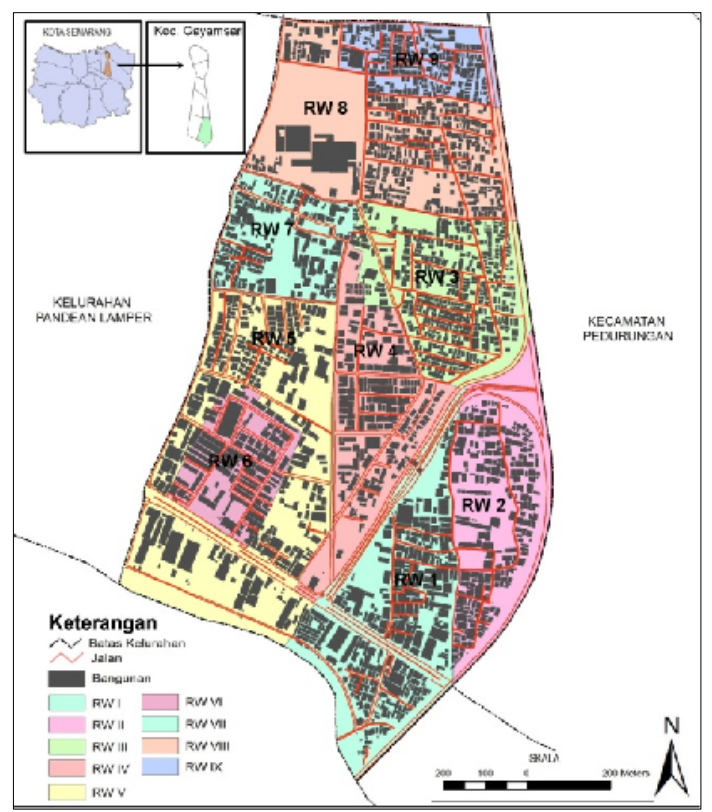

Sumber: Bappeda Kota Semarang, 2011

GAMBAR 1 DELINIASI WILAYAH STUDI 


\section{METODE PENELITIAN}

Pendekatan dalam penelitian ini adalah pendekatan kuantitatif. Pendekatan kuantitatif merupakan metode penelitian yang berlandaskan pada positivisme, digunakan untuk meneliti pada populasi atau sampel tertentu, teknik pengambilan sampel pada umumnya dilakukan secara random, pengumpulan data menggunakan instrumen penelitian, dan analisis data bersifat statistik (Sugiyono, 2007). Pendekatan ini digunakan untuk melakukan pengujian terhadap teori-teori yang ditetapkan sebelumnya dengan menetapkan indikator dan mengukurnya di lapangan.

\section{Teknik Pengumpulan Data}

Teknik pengumpulan data dalam penelitian ini yaitu melalui pengumpulan sumber data primer dan sumber data sekunder. Pengumpulan data primer yaitu melalui observasi lapangan, kuesioner, dan wawancara. Sedangkan pengumpulan data sekunder yaitu melalui kajian dokumen dan literatur. Objek penelitian dalam penelitian ini adalah seluruh staff pemerintah Kelurahan Gayamsari dan masyarakat sebagai pembanding informasi kinerja pemerintah kelurahan dalam melaksanakan program green-village. Teknik sampling untuk pemerintah kelurahan adalah metode non-probability sampling dengan metode sensus. Metode sensus adalah teknik penentuan sampel yang digunakan bila semua anggota populasi digunakan sebagai sampel, serta sering dilakukan jika jumlah populasi relatif kecil (kurang dari 30 orang) (Sugiyono, 2007). Hal ini dilakukan karena jumlah staff kelurahan relatif kecil yaitu kurang dari 30 orang, yaitu 15 orang. Peneliti juga ingin membuat generalisasi tingkat kedetailan tinggi sehingga seluruh populasi pemerintah kelurahan diteliti dan dijadikan sampel. Untuk masyarakat Kelurahan Gayamsari, menggunakan teknik sampling kuota. Menurut Sugiyono (2007) sampling kuota adalah teknik untuk menentukan sampel dari populasi yang mempunyai ciri-ciri tertentu sampai kuota yang diinginkan. Pada penelitian ini, dibutuhkan masyarakat yang mengetahui mengenai green-village, maka sampel yang dipilih harus memenuhi kriteria tersebut. Dasar pemilihan teknik sampling quota adalah dimana penarikan sampel dilakukan atas dasar pertimbangan peneliti untuk tujuan meningkatkan representasi sampel penelitian sampai jumlah tertentu sebagaimana yang dikehendaki peneliti. Oleh karena itu dalam penelitian ini peneliti menetapkan jumlah responden sejumlah 30 orang yang mengetahui program green-village.

\section{Teknik Analisis}

Pada penelitian ini akan digunakan metode analisis statistik dekriptif kuantitatif. Dalam penelitian ini, teknik analisis deskriptif kuantitatif digunakan untuk menerjemahkan hasil data kuesioner untuk mendapatkan penilaian kinerja pemerintah Kelurahan Gayamsari dalam mewujudkan permukiman green-village. Metode analisis yang digunakan adalah deskriptif kuantitatif dengan alat analisis distribusi frekuensi dan analisis skoring. Analisis skoring digunakan untuk menilai kriteria atau penilaian tertentu menggunakan skala terukur. Dalam menganalisis skoring, tujuan akhirnya adalah akan melihat kinerja pemerintah yang diinterpretasikan melalui klasifikasi total skor yang akan diinterpretasikan menjadi ukuran kinerja pemerintah. Untuk menentukan jarak interval antara penentuan hasil skor buruk hingga baik digunakan rumus sebagai berikut (Widoyoko, 2012).

$$
\text { Jarak in:erval }(\mathrm{i})=\frac{\text { Skor tertinggi }- \text { skor terendah }(R)}{\text { Jumlah kelas interval }(\mathrm{K})}
$$

Untuk interpretasi hasil skor dan prosentase maka prosentase kinerja dikategorikan dalam interval kelas yang sudah didapat, maka penentuan klasifikasi skor \& prosentase kinerja adalah sebagai berikut. 
TABEL 1

TINGKAT KINERJA BERDASARKAN KLASIFIKASI SKOR / PROSENTASE

\begin{tabular}{|c|c|c|c|c|}
\hline $\begin{array}{l}\text { Interval Skor } \\
\text { Kelurahan }\end{array}$ & $\begin{array}{l}\text { Interval Skor } \\
\text { Masyarakat }\end{array}$ & $\begin{array}{l}\text { Interval } \\
\text { Prosentase }\end{array}$ & Tingkat & Perwujudan Kinerja \\
\hline $15-26,25$ & $30-52,50$ & $25 \%-43,75 \%$ & $\begin{array}{l}\text { Sangat } \\
\text { Buruk }\end{array}$ & $\begin{array}{l}\text { Kinerja sangat buruk (belum semua } \\
\text { indikator diterapkan) }\end{array}$ \\
\hline $26,26-37,51$ & $52,51-75,01$ & $43,76 \%-62,51 \%$ & Buruk & $\begin{array}{l}\text { Kinerja buruk dan masih perlu banyak } \\
\text { pemaksimalan }\end{array}$ \\
\hline $37,52-48,77$ & $75,02-97,52$ & $62,52 \%-81,28 \%$ & $\begin{array}{l}\text { Cukup } \\
\text { Baik }\end{array}$ & $\begin{array}{l}\text { Kinerja cukup baik namun masih perlu } \\
\text { pemaksimalan(sudah menerapkan } \\
\text { beberapa indikator) }\end{array}$ \\
\hline $48,78-60,00$ & $97,53-120$ & $81,29 \%-100 \%$ & Baik & $\begin{array}{l}\text { Kinerja sudah baik (sudah menerapkan } \\
\text { indikator secara maksimal) }\end{array}$ \\
\hline
\end{tabular}

Sumber : Hasil Analisis Penyusun, 2014

\section{GAMBARAN UMUM}

Kelurahan Gayamsari termasuk dalam Bagian Wilayah Kota $V$ dalam pengembangan Kota Semarang. Sesuai dengan arahan Rencana Tata Ruang Kota Semarang bahwa fungsi primer BWK V ditetapkan untuk kegiatan perdagangan dan jasa, pusat transportasi, kawasan permukiman dengan kepadatan sedang sampai tinggi. Kelurahan Gayamsari termasuk dalam arahan lokasi permukiman yang didukung dengan adanya pusat perdagangan dan transportasi. Dampaknya adalah adanya peningkatan kebutuhan akan hunian dan tingginya built up area sehingga menyebabkan minimnya ruang terbuka hijau pada Kelurahan Gayamsari. Selain itu dengan adanya kondisi drainase yang buruk, sehingga sering terjadi banjir pada kawasan permukiman. Di tengah permasalahan lingkungan yang terjadi, pemerintah kelurahan mencoba menerapkan program Gayamsari Green-village untuk mewujudkan kelurahan yang ramah lingkungan.

\section{Program Gayamsari Green-village}

Gayamsari green-village merupakan program yang diinisiasi oleh pemerintah kelurahan untuk mewujudkan Kelurahan Gayamsari yang ramah lingkungan. Program dicanangkan pada tahun 2010 dengan didasarkan pada dasar hukum yaitu Undang - undang Nomor 23 Tahun 1997 tentang Pengelolaan Lingkungan Hidup, Peraturan Pemerintah Nomor 41 Tahun 1999 tentang Pengendalian Pencemaran Udara, Surat Walikota Semarang Nomor Tahun 2011 tentang Pelaksanaan Lomba Lingkungan Kelurahan Tingkat Kota Semarang Tahun 2011, dan Surat Keputusan Lurah Tahun 2010 Tentang Perbaikan Kualitas Lingkungan. Tujuan program adalah meningkatkan peran serta dan memberdayakan warga di wilayah RT, RW dan Kelurahan untuk mencintai, mengembangkan dan menjaga lingkungan guna menciptakan Kelurahan Gayamsari yang bersih, hijau dan berwawasan lingkungan. Sasaran program adalah meningkatkan kualitas lingkungan permukiman, mengatasi permasalahan lingkungan yaitu banjir, polusi udara, kegiatan penghijauan dan ramah lingkungan, dan termotivasinya masyarakat untuk membudayakan lingkungan bersih, sehat dan berkelanjutan. Rencana kerja yang ada yaitu green design penghijauan kawasan, pengelolaan sampah rumah tangga mandiri, perbaikan dan pemeliharaan infrastruktur, edukasi perilaku ramah lingkungan, dan kelembagaan peduli lingkungan. Sumber dana untuk program ini adalah dana MUSRENBANG, dana strategis APBD, CSR, dan swadaya masyarakat. Kinerja yang sudah dilakukan kelurahan adalah membuat taman kelurahan di Jalan Kanguru Raya, penghijauan dan pembuatan jalur hijau turus Jalan Slamet Riyadi dan Jalan Kanguru Raya, optimalisasi penghijauan rumah (tanaman obat dan tanaman hias), dan pemanfaatan sampah untuk daur ulang dan kompos di RW 4. Pihak kelurahan juga 
menerapkan kader lingkungan, dimana bertugas sebagai lembaga yang fokus pada kegiatan penghijauan. Lembaga ini dinamakan Kelompok Masyarakat Peduli Lingkungan yang dibagi dengan 5 fokus wilayah , yaitu KMPL Gajah, KMPL Kijang, KMPL Kanguru, KMPL Beruang, dan KMPL Slamet Riyadi.

\section{KAJIAN TEORI}

Kinerja merupakan hasil dari kegiatan yang dilakukan dalam mencapai tujuan yang ditetapkan, dan tujuannya adalah untuk memperkuat sejauh mana pemerintah mencapai tujuan mereka. Secara lebih lengkap, dijelaskan pula oleh DARPG (Department of Administrative Reforms \& Public Grievances) (2009) bahwa kinerja atau 'performances' mengacu pada kemampuan pemerintah untuk menggunakan sumber daya (input) dan menggunakannya secara sesuai dan efisien dalam hubungan input - output hingga outcome sehingga hasil dari program dapat mencapai hasil yang diinginkan. Menurut Boyle (2000), kinerja pemerintah di tingkat lokal/kelurahan merupakan hal yang penting, sehingga pengukuran kinerja menjadi aspek utama dalam elemen pemerintah lokal, yang diukur melalui tiga dimensi yaitu dari segi input, proses, output, dan outcome. Oleh karena itu dapat disimpulkan bahwa kinerja merupakan suatu tingkat pencapaian hasil kerja pemerintah dari suatu program/kegiatan yang dapat secara baik mencapai tujuan melalui identifikasi elemen input hingga outcome.

Pengukuran kinerja menjadi sesuatu yang penting dalam menjadi alat dalam mengevaluasi pencapaian kinerja pemerintah dalam kaitannya dengan efektivitas kegiatan/program. GAO (General Accounting office) (1998) menyatakan bahwa pengukuran kinerja adalah suatu kegiatan pemantauan dan pelaporan dari pencapaian sebuah program, khususnya kemajuan dalam mencapai tujuan pembangunan, serta pengukuran kinerja ini diukur dari aspek proses (aktivitas program), hasil dari program (output) dan berfungsinya hasil program (outcome). Menurut VAGO (Victorian Auditor General's office) (2012) terdapat beberapa konsep penting dalam pengukuran kinerja agar kinerja dipahami secara jelas dan terstruktur yaitu sebagai berikut.

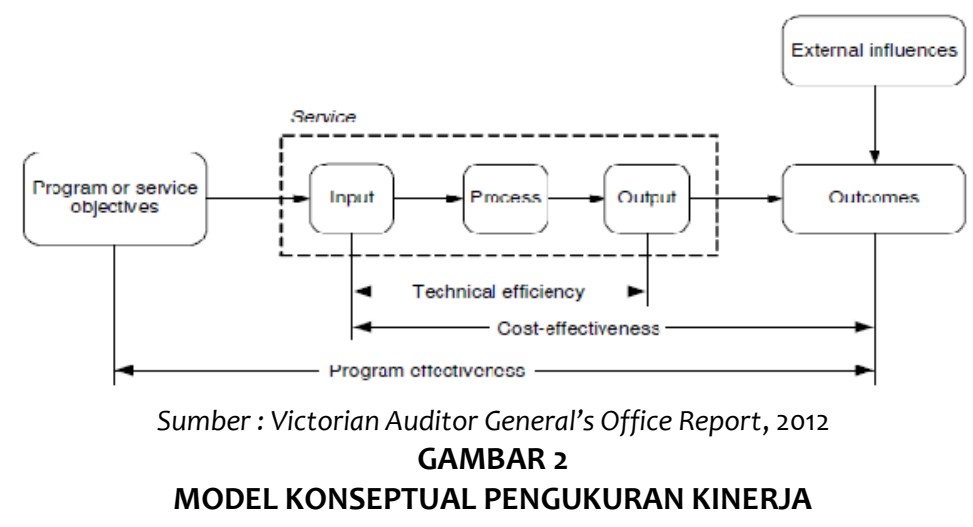

\section{Definisi Pemerintah Kelurahan}

Kelurahan merupakan level terendah dari pemerintah dalam hirarki administrasi di Indonesia. Kelurahan (village) merupakan unit administrasi terendah di bawah kecamatan (sub districts) (Zakaria, 2003). Pemerintah kelurahan merupakan level pemerintahan paling rendah dan merupakan unit administrasi dibawah kecamatan, serta sedikit berbeda dengan desa karena desa merupakan unit administrasi yang kepalanya dipilih oleh warga, sedangkan lurah merupakan pegawai negeri sipil, dan keduanya memiliki peraturan yang berbeda. Dalam 
pelaksanaan tugasnya, pemerintah kelurahan tidak bebas untuk mengelola sendiri pemerintahannya karena kelurahan merupakan bagian otonomi dari pemerintah diatasnya, sehingga seringkali pemerintah kelurahan sangat tergantung pada kebijakan diatasnya dan anggaran dari pemerintah diatasnya. Oleh karena itu mengingat pemerintah kelurahan merupakan level pemerintah terdekat dengan masyarakat yang sangat menentukan kesejahteraan masyarakat, maka dibutuhkan kinerja pemerintah kelurahan yang baik di dalam menerapkan inovasi mengenai peningkatan kualitas hidup masyarakatnya.

\section{Definisi Green-village}

Menurut Kadave et al (2012), Green-village adalah merupakan sebuah konsep yang menjaga sebuah kampung atau permukiman untuk mencapai pembangunan berkelanjutan, dengan tujuan perencanaan yang didasarkan pada konservasi lingkungan, energi, pengelolaan sampah, konservasi sumber air, dan sebagainya. Adanya konsep green-village ditujukan untuk mengatasi permasalahan lingkungan dengan prinsip hijau disetiap pembangunannya. Intinya adalah tetap melakukan konservasi hijau atau mempertahankan ruang terbuka hijau, memiliki perilaku ramah lingkungan, pengolahan sampah dan limbah, dan sebagainya. Prinsip greenvillage tidak jauh berbeda dengan eco-village. Menurut Leadership In Energy and Environmental Design (LEED) (2013), prinsip dari green-village adalah konservasi lingkungan, pengelolaan dan pengolahan sampah, pembaruan energi, penghematan energi, penghematan sumber daya air, tata ruang hijau, dan sebagainya. Adanya green-village ini menjadi konsep yang seharusnya diterapkan pada permukiman pada saat ini. Konsep eco-village/green-village juga tidak akan berhasil jika tidak didukung oleh pencapaian yang baik dari keempat aspek yaitu ekologi, ekonomi, sosial, dan kelembagaan yang baik (Suryani, 2011). Konsep greenvillage ini sangat tergantung pada aktor yang melaksanakannya. Aktor disini yaitu pemerintah sebagai institusi formal yang berwenang, dan masyarakat sebagai objek utama dalam pembangunan.

\section{ANALISIS}

\section{Kinerja Pemerintah Kelurahan dalam Mewujudkan Program Green-village}

Dalam analisis ini akan ditinjau kinerja kelurahan melalui 4 variabel yaitu kinerja kelurahan dalam penyusunan program green-village, kinerja dalam penyelenggaraan tata kelola, kinerja dalam penyelenggaraan kerjasama dengan masyarakat \& lembaga lain, dan kinerja dalam kegiatan pasca program.

Kinerja pemerintah kelurahan dalam mewujudkan permukiman green-village dalam kategori cukup baik, dengan prosentase $63,13 \%$. Kategori ini cenderung cukup yang mendekati rendah, hal ini dikarenakan masih adanya beberapa variabel yang memiliki tingkat kinerja buruk. Kinerja dalam penyusunan program mendapatkan hasil 53.96\% yang termasuk dalam kategori buruk. Kategori ini didapatkan karena hasil dari penilaian beberapa indikator yang mendapatkan hasil rendah, seperti keterlibatan dalam pemutusan, tidak adanya panduan dalam indikator green-village, dan kurangnya implementasi indikator green-village di lapangan. Dalam pelaksanaan green-village, tidak ada panduan yang secara jelas mengatur atau mengharuskan masyarakat harus melaksanakan pengelolaan sampah, penggunaan teknologi ramah lingkungan, maupun menerapkan perilaku ramah lingkungan dalam keseharian. Hal ini merupakan faktor yang menyebabkan rendahnya kinerja pemerintah kelurahan dalam mewujudkan green-village. Dari aspek rencana kerja, tujuan visi misi, rencana anggaran dan target sudah cukup baik dan jelas tersedia sehingga menjadi modal dalam pelaksanaan proses program. Kinerja pemerintah kelurahan dalam penyelenggaraan tata kelola berada dalam 
kategori baik, dengan kinerja 82.38\%. Kinerja dalam kerjasama dengan masyarakat dan lembaga lainnya, berada dalam kategori baik, dengan kinerja $83.33 \%$. Koordinasi yang baik ini dibuktikan dalam hal pemeliharaan infrastruktur seperti pavingisasi jalan yang merupakan usulan dari masyarakat, dapat ditampung dan diselesaikan oleh kelurahan. Koordinasi ini dipengaruhi oleh faktor kedekatan pemerintah kelurahan dengan masyarakat dan peningkatan koordinasi yang dilakukan melalui rapat rutin dan pertemuan rutin antar pengurus Kelurahan, pengurus RW, RT, dan LPMK. Hal ini menjadi modal yang sangat baik bagi perkembangan dan keberlanjutan program green-village kedepannya. Kinerja pemerintah kelurahan dalam kegiatan pasca program green-village, berada dalam kategori buruk, dengan prosentase 52.22\%. Pemantauan setelah green-village tidak dilaksanakan. Pemantauan seharusnya dilakukan untuk memantau hasil program agar dimanfaatkan dengan baik oleh masyarakat. Hal ini dapat menyebabkan green-village tidak berkelanjutan.

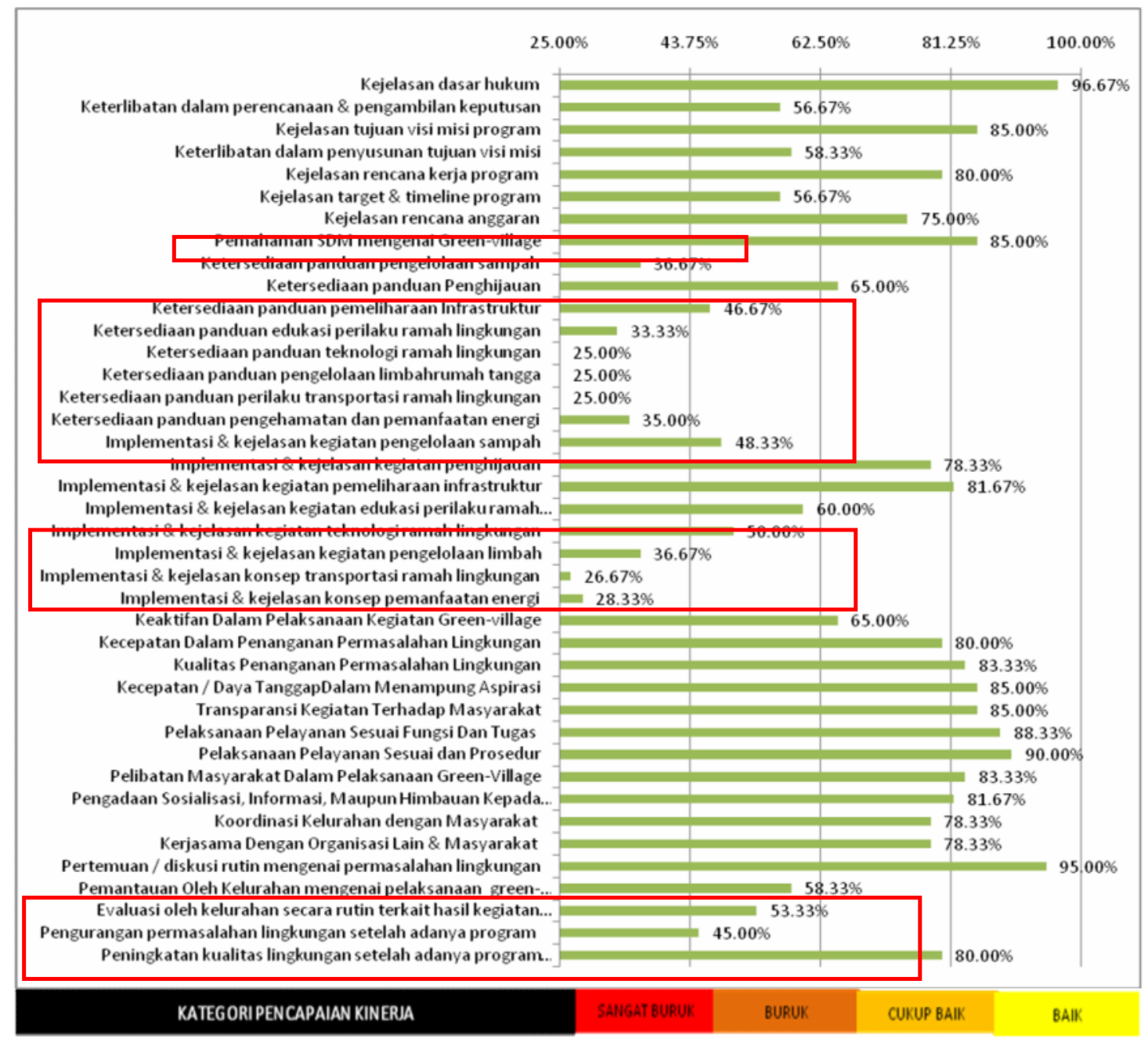

Sumber: Hasil Analisis Penyusun, 2014

GAMBAR 3

PROSENTASE CAPAIAN KINERJA KELURAHAN DALAM PENYUSUNAN PROGRAM

Kinerja Pemerintah dalam Mewujudkan Program Green-village Menurut Masyarakat

Dalam analisis ini akan ditinjau kinerja kelurahan melalui variabel kinerja kelurahan dalam penyusunan program green-village, kinerja dalam penyelenggaraan tata kelola, kinerja dalam 
penyelenggaraan kerjasama dengan masyarakat \& lembaga lain, dan kinerja dalam kegiatan pasca program berdasarkan penilaian masyarakat.

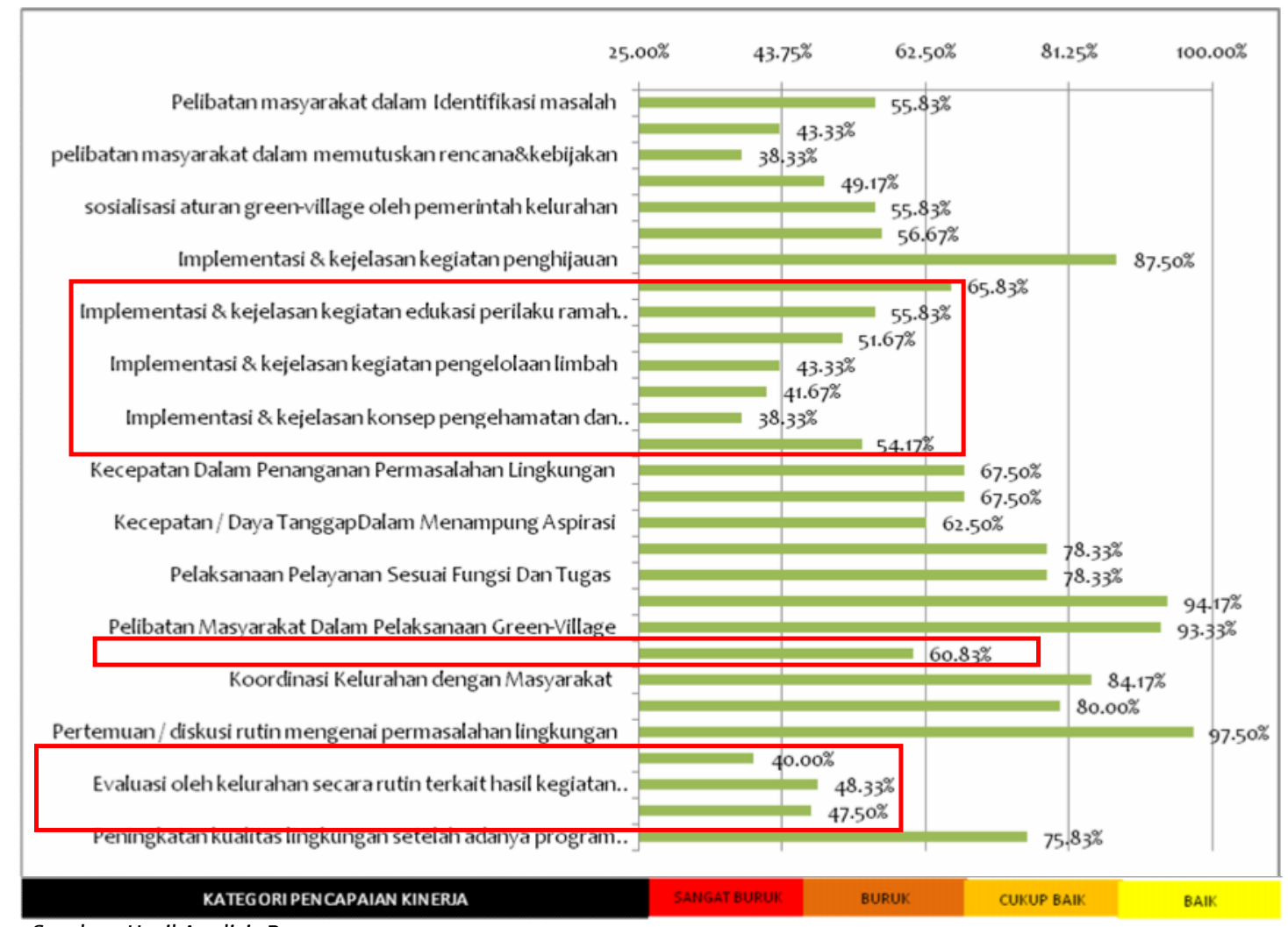

Sumber: Hasil Analisis Penyusun, 2014

\section{GAMBAR 4 \\ PROSENTASE CAPAIAN KINERJA KELURAHAN MENURUT MASYARAKAT}

Kinerja pemerintah kelurahan dalam mewujudkan permukiman green-village menurut masyarakat dalam kategori cukup baik, dengan prosentase $62.53 \%$. Kinerja dalam penyusunan program mendapatkan hasil kinerja $52.56 \%$ yang termasuk dalam kategori buruk. Kategori ini didapatkan karena hasil penilaian beberapa indikator yang mendapatkan hasil rendah, seperti keterlibatan masyarakat dalam pemutusan, penyusunan rencana kerja, tidak adanya sosialisasi aturan terkait green-village. Adanya hal ini merupakan faktor yang menyebabkan rendahnya kinerja pemerintah kelurahan dalam mewujudkan green-village. Kinerja pemerintah kelurahan dalam penyelenggaraan tata kelola, dalam kategori cukup baik, dengan prosentase $\mathbf{7 1 . 7 9 \%}$. Dalam aspek transparansi, kecepatan menampung aspirasi, kinerja dalam pelaksanaan tugas dalam rangka green-village berada dalam kategori cukup baik. Namun dalam aspek keaktifan dan daya tanggap, masyarakat menyatakan bahwa kinerja pemerintah kelurahan dalam kategori buruk. Kinerja dalam kerjasama dengan masyarakat dan lembaga lainnya, berada dalam kategori baik, dengan prosentase $83.17 \%$. Kinerja pemerintah kelurahan dalam kegiatan pasca program green-village menurut masyarakat, berada dalam kategori sangat buruk, dengan prosentase $\mathbf{5 2 . 9 2 \% . ~ K e g i a t a n ~ p e m a n t a u a n ~ s e t e l a h ~ a d a n y a ~ g r e e n - v i l l a g e ~ t i d a k ~}$ dilaksanakan. Masyarakat mengaku kelurahan tidak pernah memantau rutin kegiatan penghijauan atau pemeliharaan infrastruktur. Pemantauan lebih diserahkan kepada RT dan RW, artinya setelah program selesai, kelurahan menyerahkan tanggung jawab sepenuhnya pada masyarakat. 
Perbandingan Kinerja dalam Mewujudkan Green-village Menurut Pemerintah \& Masyarakat Didapatkan hasil bahwa masih terdapat gap atau ketidaksesuaian hasil kinerja menurut pemerintah kelurahan dan masyarakat. Dalam hal implementasi kegiatan edukasi terhadap masyarakat mengenai perilaku ramah lingkungan, keaktifan dalam pelaksanaan kegiatan green-village, kecepatan/daya tanggap dalam menampung aspirasi dan kebutuhan masyarakat, serta pengadaan sosialisasi, informasi, himbauan mengenai program gayamsari green-village kepada masyarakat memiliki ketidaksesuaian dengan hasil kinerja pemerintah kelurahan. Ketidaksesuaian tersebut dikarenakan terjadinya perbedaan persepsi dari kelurahan dan masyarakat, dimana dalam beberapa aspek kelurahan menyatakan sudah baik namun masyarakat menganggapnya buruk. Khususnya untuk aspek pemantauan kegiatan lingkungan, keaktifan kelurahan juga dinilai kurang. Hal ini menyebabkan banyak kegiatan kurang terkontrol seperti pelaksanaan normalisasi saluran Jalan Gajah Raya yang berhenti karena kurang responsnya pemerintah kelurahan. Berbeda dengan apa yang dikatakan oleh pemerintah kelurahan bahwa mereka sudah melakukan pemantauan. Hal ini berarti bahwa sebenarnya pemerintah sudah melakukan kegiatan pemantauan terkait hasil kegiatan greenvillage, namun hanya sesekali dan tidak berkelanjutan.

\section{Analisis Kinerja Secara Keseluruhan (Analisis Input, Proses, Output, dan Outcome)}

Kinerja keseluruhan dianalisis melalui analisis input, proses, output, dan outcome dari pelaksanaan program.

\section{Analisis Kinerja Input Program}

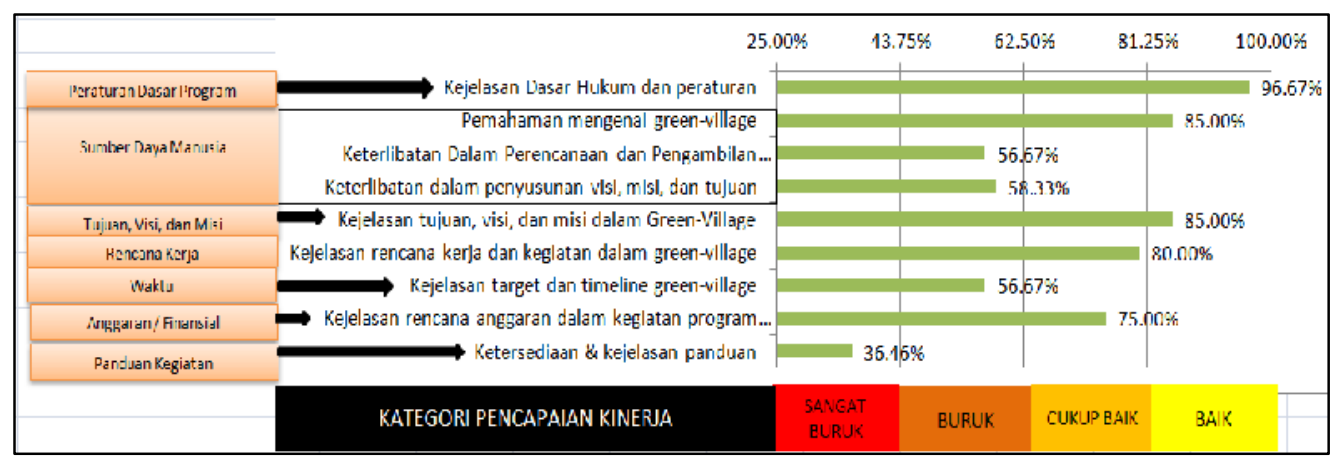

Sumber : Hasil Analisis Penyusun, 2014

\section{GAMBAR 5 \\ PROSENTASE CAPAIAN KINERJA INPUT}

Kinerja input dalam kategori cukup baik, sehingga cukup baik pula untuk menjadi modal yang dibutuhkan agar pelaksanaan green-village dapat berjalan dan menghasilkan output. Faktor yang menyebabkan kinerja input adalah adanya peraturan dasar program serta tujuan, visi, dan misi yang baik. Beberapa faktor tersebut menjadi kelebihan yang mendukung tingkat keberhasilan proses. Secara umum program green-village telah dilaksanakan dengan cukup baik, karena pemerintah kelurahan dengan berbagai keterbatasan yang ada seperti minimnya anggaran, kelurahan dapat tetap melaksanakan dan mempunyai inisiatif untuk meminta bantuan dari pihak lain untuk pelaksanaan green-village. Dari sisi waktu, penyelenggaraan green-village juga dikatakan cukup efektif karena pelaksanaan yang sesuai target, namun dalam kegiatan pemantauan dan evaluasi kelurahan tidak melakukan sehingga tidak sesuai target. 


\section{Analisis Kinerja Proses Program}

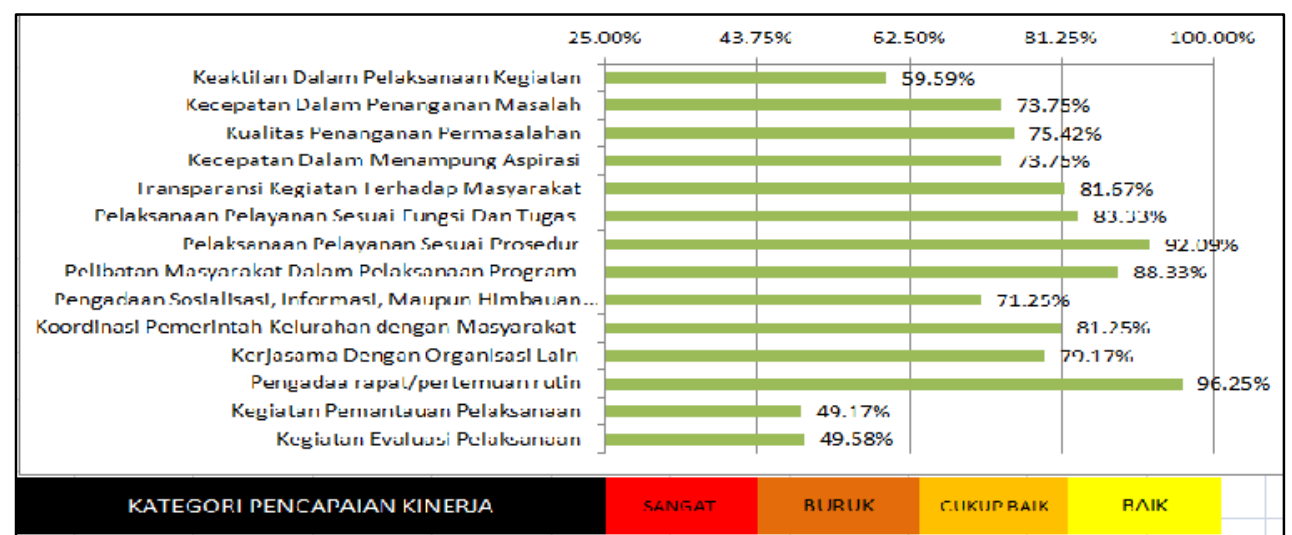

Sumber: Hasil Analisis Penyusun, 2014

GAMBAR 6

PROSENTASE CAPAIAN KINERJA PROSES

Kinerja proses dalam kategori cukup baik, sehingga dapat disimpulkan bahwa pemerintah kelurahan beserta jajarannya cukup baik dalam menggunakan input dalam pelaksanaan kegiatan green-village. Faktor pelibatan masyarakat dalam pelaksanaan program, keaktifan, kecepatan dan kualitas penanganan masalah, transparansi, koordinasi, dan kerjasama menjadi penentu kinerja yang cukup baik. Sedangkan faktor sosialisasi, informasi, dan himbauan kepada masyarakat serta kecepatan dalam menampung aspirasi tergolong buruk. Hal tersebut menjadi kekurangan dan menghambat implementasi program.

\section{Analisis Kinerja Output Program}

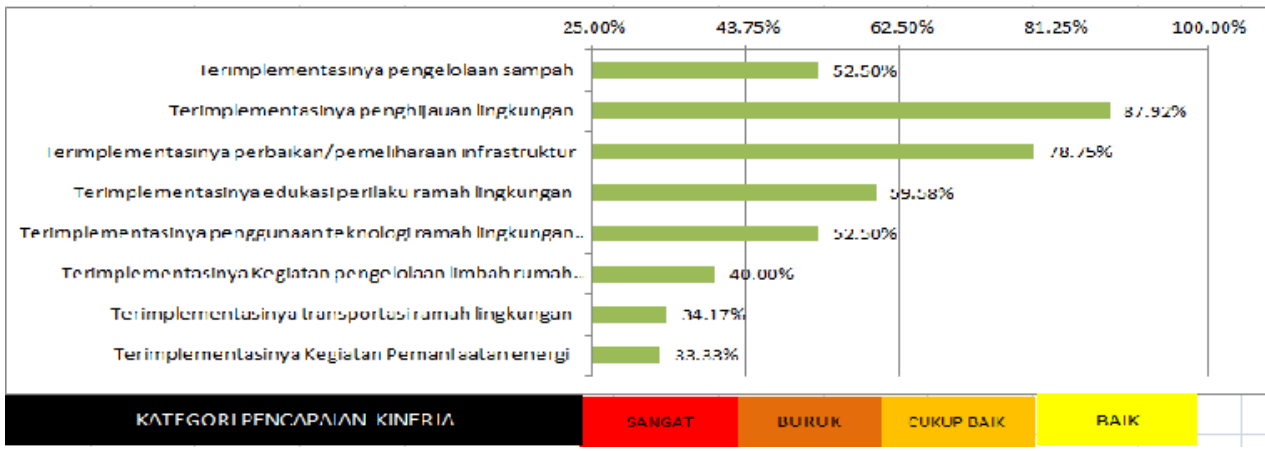

Sumber: Hasil Analisis Penyusun, 2014

GAMBAR 7

PROSENTASE CAPAIAN KINERJA OUTPUT

Kinerja output dalam kategori buruk, karena masih terdapat beberapa implementasi program yang buruk seperti pengelolaan sampah, edukasi ramah lingkungan, teknologi ramah lingkungan, dan pengelolaan limbah rumah tangga. Untuk implementasi yang sudah baik adalah kegiatan penghijauan dan pemeliharaan infrastruktur. Tidak terimplementasinya output ini disebabkan adanya faktor kapasitas kelurahan yang terbatas dalam hal dana, waktu, dan tenaga untuk melakukannya, serta masih sulitnya masyarakat untuk lebih antusias menerapkan perilaku ramah lingkungan. 


\section{Kinerja Outcome}

TABEL 3 KINERJA OUTCOME

\begin{tabular}{|c|c|c|c|c|}
\hline \multirow{2}{*}{ Aspek } & \multirow{2}{*}{ Indikator } & \multirow{2}{*}{$\begin{array}{l}\text { Realisasi } \\
\text { Capaian }\end{array}$} & \multicolumn{2}{|c|}{ Kinerja } \\
\hline & & & \% Capaian & Kategori \\
\hline $\begin{array}{l}\text { Pengurangan } \\
\text { permasalahan } \\
\text { lingkungan } \\
\text { setelah green- } \\
\quad \text { village } \\
\end{array}$ & $\begin{array}{l}\text { Berkurangnya wilayah } \\
\text { yang terkena banjir (RW } 8 \\
\text { dan 9) \& menurunnya } \\
\text { intensitas banjir }\end{array}$ & $\begin{array}{l}\text { Banjir masih belum dapat teratasi karena semakin } \\
\text { meningkatnya wilayah yang terkena banjir menjadi } \\
5 \text { RW dan intensitas yang meningkat menjadi rutin } \\
\text { pada saat musim hujan }\end{array}$ & $46.25 \%$ & Buruk \\
\hline \multirow{3}{*}{$\begin{array}{c}\text { Peningkatan } \\
\text { kualitas } \\
\text { lingkungan } \\
\text { setelah adanya } \\
\text { program } \\
\text { Gayamsari } \\
\text { green-village }\end{array}$} & $\begin{array}{l}\text { Meningkatnya } \\
\text { kenyamanan lingkungan } \\
\text { sebagai upaya } \\
\text { mengurangi polusi udara }\end{array}$ & $\begin{array}{l}\text { Kenyamanan yang menjadi cukup baik karena } \\
\text { implementasi pembangunan RTH publik diatas 50\% } \\
\text { (pencapaian output yang baik) }\end{array}$ & \multirow{3}{*}{$77.92 \%$} & \multirow{3}{*}{$\begin{array}{l}\text { Cukup } \\
\text { Baik }\end{array}$} \\
\hline & Peningkatan kualitas jalan & $\begin{array}{l}\text { Kualitas jalan yang cukup baik dengan } \\
\text { implementasi 50\% pavingisasi sehingga } \\
\text { meningkatkan akses dan aksesibilitas }\end{array}$ & & \\
\hline & $\begin{array}{l}\text { Peningkatan kualitas } \\
\text { drainase }\end{array}$ & $\begin{array}{l}\text { Kualitas drainase yang cukup baik dengan } \\
\text { implementasi 50\% perbaikan/normalisasi saluran } \\
\text { sehingga kapasitas saluran dapat menampung }\end{array}$ & & \\
\hline
\end{tabular}

Sumber: Hasil Analisis Penyusun, 2014

Berdasarkan analisis outcome diatas dapat diketahui bahwa permasalahan lingkungan seperti banjir, belum dapat terkurangi dan teratasi karena tidak maksimalnya kegiatan penggunaan biopori, sumur resapan, dan rain harvesting, serta kurangnya pemeliharaan dan pembersihan saluran. Namun pencapaian outcome peningkatan kualitas lingkungan dalam kategori cukup baik. Beberapa faktor yang menyebabkan tidak maksimalnya outcome untuk mencapai tujuan program adalah pencapaian output yang buruk, serta terdapat faktor eksternal seperti kurangnya kesadaran masyarakat, dan tidak ada kegiatan evaluasi dan pemantauan dari pemerintah kelurahan.

\section{KESIMPULAN}

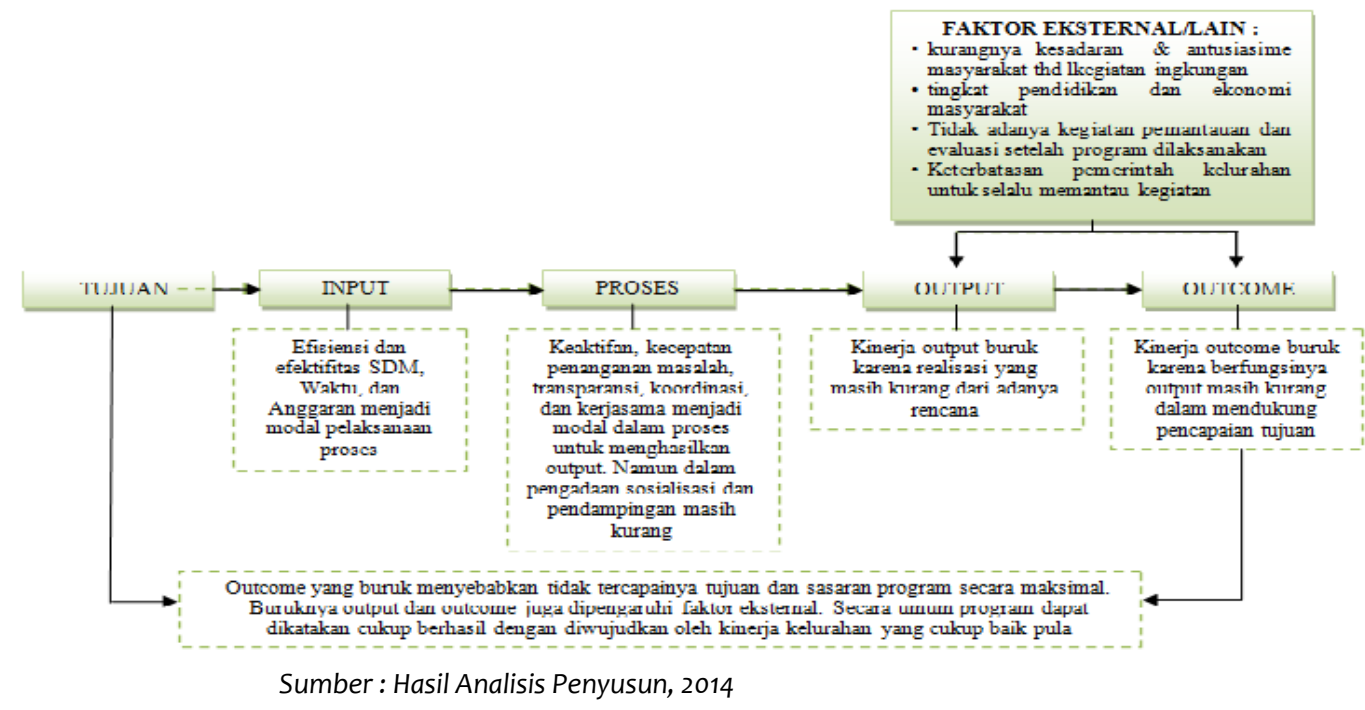

GAMBAR 8

BAGAN PENCAPAIAN HASIL KINERJA INPUT - OUTCOME 
Kinerja keseluruhan dalam mewujudkan green-village cukup baik, namun cukup baik hanya untuk pencapaian indikator penghijauan dan peningkatan kualitas lingkungan, namun dalam hal pencapaian outcome untuk mengatasi dan mengurangi permasalahan lingkungan seperti banjir, masih buruk. Hal ini disebabkan pencapaian output yang buruk pula. Banyaknya kegiatan yang tidak terimplementasi dalam output menyebabkan outcome buruk, khususnya dalam menerapkan indikator green-village. Artinya memang output sudah ada, namun sangat kurang maksimal, misalnya dalam penerapan indikator pengelolaan sampah, limbah, dan penggunaan biopori yang memang sudah terlaksana namun hanya berjalan pada saat awal program saja, dan saat ini tidak berkelanjutan. Hal ini yang menyebabkan outcome menjadi buruk pula, sehingga permasalahan lingkungan masih belum bisa diatasi. Dari segi input dan proses juga turut mempengaruhi output dan outcome yang buruk, yaitu dimana dari input jelas bahwa tidak ada panduan kegiatan yang jelas dalam melaksanakan indikator green-village sehingga pelaksanaan program berdasarkan pengetahuan masyarakat yang minim. Dari segi proses, kinerja kelurahan dalam melakukan sosialisasi dan informasi serta penyadaran lingkungan terhadap masyarakat buruk, sehingga masyarakat semakin kurang antusias dalam green-village. Faktor eksternal yang mempengaruhi buruknya output dan outcome, yaitu faktor kurangnya kesadaran dan antusiasme masyarakat terhadap kegiatan lingkungan, tidak ada kegiatan evaluasi dan pemantauan dari pemerintah terkait program, dan faktor tingkat pendidikan dan ekonomi masyarakat.

Secara garis besar dapat ditarik kesimpulan bahwa pemerintah Kelurahan Gayamsari memiliki upaya dan potensi dalam menerapkan perwujudan green-village melalui berbagai kinerja yang dilakukan. Secara tidak langsung, kinerja perwujudan green-village ini dapat menjadi rekomendasi kepada kelurahan atau pemerintah secara umum, bahwa dalam menerapkan pembangunan berwawasan lingkungan diperlukan kinerja yang maksimal, terutama dalam merubah perilaku masyarakat untuk lebih ramah lingkungan. Kinerja yang dilakukan Kelurahan Gayamsari menyebabkan upaya yang baik untuk mewujudkan green-village dan konsep tersebut menjadi solusi terbaik dalam inovasi pembangunan permukiman perkotaan saat ini.

\section{DAFTAR PUSTAKA}

Boyle, Richard. 2000. Performance Measurement In Local Government. Paper \& Reports Committee for Public Management Research Discussion. Institute of Public Administration an Foras Riarachain Ireland. Volume 15.

Department of Administrative Reforms \& Public Grievances (DARPG) India. 2009. "Performance Management in Government". Paper on 4th Civil Services Day by Centre for Good Governance India, April 2009.

General Accounting Office (GAO). 1998. "Performance Measurement and Evaluation: Definitions and Relationship". Glossary Presented in Senate Committee on Governmental Affairs April 199, United States.

Joga, Nirwono. 2013. Gerakan Kota Hijau. Jakarta: PT.Gramedia Pustaka Utama.

Kadave, P , P.Phatak, dan S.Pawar. 2012. Planning and Design of Green-village. International Journal Of Electronics, Communication, \& Soft Computing Science \& Engineering. (10-14).

Leadership In Energy and Environmental Design (LEED). 2013. Green-village In Jamaica. (http://greenvillagejamaica.com/images/Green-Village-Presentation.pdf). Diakses 18 Februari 2014.

Sugiyono. 2007. Metode Penelitian Bisnis. Bandung: Penerbit CV. Alfabeta. 
Suryani, Anih Sri. 2011. Tantangan Implementasi Konsep Eco-Settlement Dalam Undang-undang No.1 Tahun 2011 Tentang Perumahan dan Kawasan Permukiman. Dalam Jurnal Kepakaran Sekretariat Jenderal DPR RI.

United Nations Department of Economic and Social Affairs Division for Sustainable Development. 2012 (2009). "Review of implementation of agenda 21 and the rio principles".

Victorian Auditor General's Office (VAGO). 2012. "Local Government Performance Reporting Framework: Directions Paper". Paper published by Local Government Victoria, Melbourne.

Widoyoko, Eko Putro. 2012. Teknik Penyusunan Instrumen Penelitian. Yogyakarta: Pustaka Pelajar.

Zakaria, Amrin. 2003. "Decentralizing Extension to Local Governments: Indonesia Experience". Paper Presented in Regional Workshop on Operational zing Reform in Agricultural Extension in South Asia, New Delhi, 6-8 May 2003. 